\title{
$I_{K 1}$ and Cardiac Hypoxia: After the long and short QT syndromes, what else can go wrong with the inward rectifier $\mathrm{K}+$ currents?
}

\author{
Yanfang $\mathrm{Xu}^{1,3}$, Qian Zhang ${ }^{1}$, and Nipavan Chiamvimonvat ${ }^{1,2}$ \\ ${ }^{1}$ Division of Cardiovascular Medicine, University of California, Davis, Davis, CA \\ ${ }^{2}$ Department of Veterans Affairs, Northern California Health Care System, Mather, CA \\ ${ }^{3}$ Department of Pharmacology, Hebei Medical University, Shijiazhuang, China 050017
}

The inward rectifier $\mathrm{K}^{+}$current [1], $\mathrm{I}_{\mathrm{K} 1}$, is a key determinant of cardiac resting membrane potential as well as the repolarization of the terminal phase of cardiac action potentials (AP) $[2,3]$. Various genetic approaches have confirmed that Kir2.x channels underlie cardiac $\mathrm{I}_{\mathrm{K} 1 \text {, }}$ with Kir2.1 (encoded by KCNJ2 gene) contributing more than Kir2.2 [4,5]. Even though the important roles of $\mathrm{I}_{\mathrm{K} 1}$ in cardiac physiology have long been documented, its roles in cardiac arrhythmia generation have only been increasingly recognized recently [6-12] and indeed, have "lagged" behind other $\mathrm{K}^{+}$channels, e.g., KvLQT1 (encoded by KCNQ1 gene) and HERG (encoded by $\mathrm{KCNH} 2$ gene) which have been linked to several types of inherited cardiac arrhythmias and drug-induced long QT syndrome [13,14]. The article by Piao et al., in this issue of the Journal provides compelling evidence for yet another role of $\mathrm{I}_{\mathrm{K} 1}$, namely as a "first responder" during cardiac ischemia and hypoxia [15]. More importantly, the work begins to unravel some of the complex pathways cardiac cells use to defend against the common conditions of hypoxia and ischemia.

\section{Down-regulation of $\mathrm{I}_{\mathrm{K} 1}$ : Long QT syndrome}

New evidence now implicates $K C N J 2$ gene mutations and remodeling of the $\mathrm{I}_{\mathrm{K} 1}$ channel in cardiac diseases causing the functional up- or down-regulation of $\mathrm{I}_{\mathrm{K} 1 \text {, which may have a }}$ profound effect on cardiac excitability and increase the risk of life-threatening arrhythmia. In 2001, Plaster and coworker have documented several missense mutations in KCNJ2 gene in patients with Andersen-Tawil syndrome (ATS, also known as long QT syndrome type 7) [6], characterized by prolonged QT interval, cardiac arrhythmias, periodic paralysis, and dysmorphic features. Since then, more than 30 mutations in $K C N J 2$ gene have been identified and shown to be responsible for ATS. Most mutations in KCNJ2 show loss of function and dominant-negative suppression of Kir2.1 channel function. Loss of function may also result from disruption of channel regulation by the phospholipid, phosphatidylinositol 4,5-bisphosphate $\left(\mathrm{PIP}_{2}\right)$ [16], or defective trafficking [17]. The mechanisms of cellular dysfunction induced by loss-of-function mutations in $K C N J 2$ have been under intense investigation. In a study using in vivo adenoviral-mediated expression of a dominant-negative Kir2.1 mutant channels in guinea pig hearts, Miake et al. demonstrated

(C) 2007 Elsevier Ltd. All rights reserved.

Address for correspondence and proofs: Nipavan Chiamvimonvat, Division of Cardiovascular Medicine, Department of Medicine, University of California, Davis, One Shields Avenue, GBSF 6315, Davis, CA 95616, voice: (530) 754-7158, fax: (530) 754-7167, nchiamvimonvat@ucdavis.edu.

Publisher's Disclaimer: This is a PDF file of an unedited manuscript that has been accepted for publication. As a service to our customers we are providing this early version of the manuscript. The manuscript will undergo copyediting, typesetting, and review of the resulting proof before it is published in its final citable form. Please note that during the production process errors may be discovered which could affect the content, and all legal disclaimers that apply to the journal pertain. 
that suppression of $\mathrm{I}_{\mathrm{K} 1}$ decelerates the AP repolarization, prolongs AP duration (APD), and depolarizes the resting membrane potential [7]. Transgenic mice with suppressed $\mathrm{I}_{\mathrm{K} 1}$ show significant changes in surface ECG, including prolongation of QRS complexes and QT intervals [8]. Electrophysiologic study performed in an ATS patient suggests that reduced Kir2.1 current contributes to the development of delayed afterdepolarizations (DAD) and ventricular arrhythmias [18]. Simulation studies further suggest that a reduction in $\mathrm{I}_{\mathrm{K} 1}$ prolongs terminal phase of the cardiac AP, induces DAD and spontaneous arrhythmias [19]. Interestingly, both in simulation study [20] and experimental studies with canine arterially perfused wedge preparation [21], $\mathrm{I}_{\mathrm{K} 1}$ reduction prolongs APs without an increase in transmural dispersion of repolarization, which may provide hints as to why QT prolongation associated with ATS is relatively benign clinically.

\section{Down-regulation of $I_{K 1}$ in heart failure}

Down-regulation of $\mathrm{I}_{\mathrm{K} 1}$ has been observed in both experimental animal models and human heart failure [22]. The remodeling of $\mathrm{I}_{\mathrm{K} 1}$ contributes to the prolongation of APs, which is a hallmark of cardiac hypertrophy and failure and is believed to predispose the heart to afterdepolarization and reentrant arrhythmias. However, the mechanism underlying downregulation of $\mathrm{I}_{\mathrm{K} 1}$ in heart failure is not fully understood. Elevated diastolic $\mathrm{Ca}^{2+}$ in heart failure may induce the reduction of $\mathrm{I}_{\mathrm{K} 1}$ by blocking the channel or through PKC-dependent mechanisms [23]. Indeed, elucidating the molecular mechanism of $\mathrm{I}_{\mathrm{K} 1}$ remodeling in pathological conditions may offer new and potential therapeutic targets for the prevention of the electrical remodeling so as to prevent life-threatening arrhythmias.

\section{Up-regulation of $\mathrm{I}_{\mathrm{K}_{1}}$ : Short QT syndrome and familial atrial fibrillation}

More recently, Priori et al, described yet another type of hereditary channelopathy associated with $K C N J 2$ gene mutation (D172N), one which was associated with a gain of function by increasing $\mathrm{I}_{\mathrm{K} 1}$ current [9]. This gain-of-function mutation was found to be linked to short QT syndrome (SQTS type 3). SQTS is the recently discovered hereditary channelopathy characterized by a remarkably accelerated repolarization that is reflected by a shorter QT interval than normal. The D172N mutation in KCNJ2 gene results in an upregulation of $\mathrm{I}_{\mathrm{K} 1}$, which greatly accelerates the final phase of repolarization and shortens the cardiac APD in computer simulations using a human ventricular myocyte model. Clinical manifestations of SQTS include a high incidence of syncope, arrhythmias and sudden cardiac death. So far, two other forms of SQTS (SQT1 \& 2) have been identified according to the affected genes. A gain-of-function mutation in the $K C N H 2$ gene encoding $\mathrm{I}_{\mathrm{kr}}$ (the rapidly activating delayed rectifier $\mathrm{K}^{+}$current) is responsible for the SQT1 [24] and a gainof-function mutation in the $K C N Q 1$ gene underlying $\mathrm{I}_{\mathrm{ks}}$ (the slowly activating delayed rectifier $\mathrm{K}^{+}$current) causes the SQT2 [25].

In the same year, another gain-of-function mutation in $K C N J 2$ gene was identified in familial atrial fibrillation (AF) [10]. Functional expression of the Kir2.1 channel with a valine to isoleucine mutation at position 93 demonstrated a significant increase in both inward and outward current without affecting the kinetics and rectification properties of the channels. Taken together, clinical phenotypes of the above inherited cardiac diseases implicate an important role and the significance of $\mathrm{I}_{\mathrm{K} 1}$ in cardiac excitability.

Using a transgenic mouse model, cardiac specific over-expression of Kir2.1 subunits resulting in the up-regulation of $\mathrm{I}_{\mathrm{K} 1}$ leads to multiple abnormalities of cardiac excitability, including marked shortening in APD and effective refractory period (ERP), and nearcomplete elimination of the slow T wave, with a short QT interval [11]. Increased density of $\mathrm{I}_{\mathrm{K} 1}$ was also observed to be associated with other abnormalities, such as junctional escape, atrioventricular block, AF, cardiac hypertrophy, and death in the transgenic animals [11]. 
More recent evidence demonstrates that $\mathrm{I}_{\mathrm{K} 1}$ up-regulation may provide a substrate for stable reentrant arrhythmias [12].

\section{Up-regulation of $I_{K 1}$ in chronic atrial fibrillation (AF)}

In addition to the gain-of-function mutations of Kir2.1 channel, up-regulation of $\mathrm{I}_{\mathrm{K} 1}$ is a consistent finding among studies of chronic AF-induced ionic current remodeling in humans. Computer models of electrical activity of human atrial cells reveal that upregulation of $\mathrm{I}_{\mathrm{K} 1}$ has a great influence on atrial APD [26]. Remodeling of $\mathrm{I}_{\mathrm{K} 1}$ primarily contributes to APD shortening, a predominant electrophysiological change in chronic AF. Shortening of APD promotes the initiation and maintenance of multiple reentrant wavelets in a limited mass of atrial tissue and thus, contributes to the self-perpetuation of AF.

\section{Roles of $I_{\mathrm{K} 1}$ in cardiac hypoxia}

There is a large body of evidence to support $\mathrm{K}_{\mathrm{ATP}}$ channels as one of the key metabolic sensor in the cells $[27,28]$. The channels are regulated by the kinetics of the intracellular ATP and ADP ratio, which in turn is affected by various metabolic stresses [27]. Therefore, the $\mathrm{K}_{\mathrm{ATP}}$ channels provide the critical linkage between the metabolic state and membrane excitation. In the heart, $\mathrm{K}_{\mathrm{ATP}}$ channels have been shown to play important protective roles in cardiac ischemia and hypoxia [29]. On the other hand, the roles of $\mathrm{I}_{\mathrm{K} 1}$ channels in cardiac hypoxia are only beginning to emerge.

In this issue of the Journal, a comprehensive study reported by Piao and coworkers provided evidence demonstrating that $\mathrm{I}_{\mathrm{K} 1}$ is activated early during hypoxia in cardiomycytes [15]. Under normal conditions, $\mathrm{I}_{\mathrm{K} 1}$ channels are constitutively active while $\mathrm{K}_{\mathrm{ATP}}$ channels are closed. By taking advantage of a transgenic mouse model with cardiac-specific expression of a dominant-negative form of Kir2.1, the study provides new evidence to suggest that $\mathrm{I}_{\mathrm{K} 1}$ underlies the observed early AP shortening during hypoxia before $\mathrm{K}_{\mathrm{ATP}}$ channel is activated. Specifically, in the transgenic hearts, cardiac AP shortening in response to hypoxia was significantly delayed compared to wild-type hearts. Moreover, the early AP shortening induced by cyanide (to block oxidative phosphorylation) seen in wild-type cardiac myocytes was completely eliminated in cardiac myocytes isolated from transgenic animals. The data supported the previous notion that functional up-regulation of $\mathrm{I}_{\mathrm{K} 1}$ underlies early APD shortening during hypoxia. Results from these earlier studies in hypoxic rabbit hearts and guinea-pig cardiomyocytes treated by inhibitors of oxidative phosphorylation suggested an early increase of $\mathrm{I}_{\mathrm{K} 1}$ preceding the activation of $\mathrm{K}_{\mathrm{ATP}}$ channels [30,31]. In comparison to these earlier studies, the use of genetically altered mouse model in the present study provides the opportunity to directly test the involvement of $\mathrm{I}_{\mathrm{K} 1}$ without the limitation of pharmacological approaches. Nonetheless, it remains unknown whether the observed phenomenon is generalizable to other species or hypoxic models.

This interesting study raises many important mechanistic questions. Perhaps one of the most intriguing issues is the cellular mechanisms responsible for the early activation of $\mathrm{I}_{\mathrm{K} 1}$ during cardiac hypoxia. The authors showed that the activation of $\mathrm{I}_{\mathrm{K} 1}$ was dependent on intracellular $\mathrm{Ca}^{2+}$ and sarcoplasmic reticulum (SR) $\mathrm{Ca}^{2+}$ release. Specifically, intracellular $\mathrm{Ca}^{2+}$ buffering with BAPTA or pharmacological inhibition of $\mathrm{SR} \mathrm{Ca}^{2+}$ release resulted in the complete inhibition of $\mathrm{I}_{\mathrm{K} 1}$ activation in their experimental model. On the other hand, the exact signaling pathways involved or the molecular events underlying $\mathrm{I}_{\mathrm{K} 1}$ activation by intracellular $\mathrm{Ca}^{2+}$ during hypoxia remain unclear. In particular, previous study has documented the voltage-dependent block of $\mathrm{I}_{\mathrm{K} 1}$ by intracellular $\mathrm{Ca}^{2+}$ [23]. Moreover, several other possible mechanisms may come into play during cardiac ischemia and hypoxia including alteration in intracellular $\mathrm{pH}$ and polyamines, both of which can significantly modulate $\mathrm{I}_{\mathrm{K} 1}$ [32]. The involvement of other ionic currents or transporters during ischemia 
and hypoxia cannot be completely ruled out [33]. Finally, recognizing the possible proarrhythmic effects of $\mathrm{I}_{\mathrm{K} 1}$ activation and the resultant $\mathrm{AP}$ abbreviation, it remains to be clarified by future experiments whether the observed phenomenon plays a protective role for cardiac myocyte survival and function.

In sum, in addition to the well established effects of $\mathrm{K}_{\mathrm{ATP}}$ channel in cardioprotection, the results from the study by Piao et al. [15], may open a new door into the complex cellular responses during myocardial hypoxia and ischemia. Ultimately, defining these interrelated signaling pathways is essential for advancing our understanding of the molecular mechanisms underlying arrhythmia genesis during cardiac ischemia.

\section{Acknowledgments}

Supported in part by the Department of Veteran Affairs Merit Review Grant and the National Institutes of Health Grants (HL 75274 and HL 85844 to N.C.).

\section{References}

1. Hutter OF, Noble D. Rectifying properties of heart muscle. Nature. 1960; 188:495. [PubMed: 13717088]

2. Ibarra J, Morley GE, Delmar M. Dynamics of the inward rectifier $\mathrm{K}^{+}$current during the action potential of guinea pig ventricular myocytes. Biophys J. 1991; 60:1534-9. [PubMed: 1777570]

3. Nichols CG, Lopatin AN. Inward rectifier potassium channels. Annu Rev Physiol. 1997; 59:171-91. [PubMed: 9074760]

4. Zaritsky JJ, Eckman DM, Wellman GC, Nelson MT, Schwarz TL. Targeted disruption of Kir2.1 and Kir2.2 genes reveals the essential role of the inwardly rectifying $\mathrm{K}^{+}$current in $\mathrm{K}^{+}$-mediated vasodilation. Circ Res. 2000; 87:160-6. [PubMed: 10904001]

5. Zobel C, Cho HC, Nguyen TT, Pekhletski R, Diaz RJ, Wilson GJ, Backx PH. Molecular dissection of the inward rectifier potassium current $\left(\mathrm{I}_{\mathrm{K} 1}\right)$ in rabbit cardiomyocytes: evidence for heteromeric co-assembly of Kir2.1 and Kir2.2. J Physiol. 2003; 550:365-72. [PubMed: 12794173]

6. Plaster NM, Tawil R, Tristani-Firouzi M, Canun S, Bendahhou S, Tsunoda A, Donaldson MR, Iannaccone ST, Brunt E, Barohn R, Clark J, Deymeer F, George AL Jr, Fish FA, Hahn A, Nitu A, Ozdemir C, Serdaroglu P, Subramony SH, Wolfe G, Fu YH, Ptacek LJ. Mutations in Kir2.1 cause the developmental and episodic electrical phenotypes of Andersen's syndrome. Cell. 2001; 105:511-9. [PubMed: 11371347]

7. Miake J, Marban E, Nuss HB. Functional role of inward rectifier current in heart probed by Kir2.1 overexpression and dominant-negative suppression. J Clin Invest. 2003; 111:1529-36. [PubMed: 12750402]

8. McLerie M, Lopatin AN. Dominant-negative suppression of $\mathrm{I}_{\mathrm{K} 1}$ in the mouse heart leads to altered cardiac excitability. J Mol Cell Cardiol. 2003; 35:367-78. [PubMed: 12689816]

9. Priori SG, Pandit SV, Rivolta I, Berenfeld O, Ronchetti E, Dhamoon A, Napolitano C, Anumonwo J, di Barletta MR, Gudapakkam S, Bosi G, Stramba-Badiale M, Jalife J. A novel form of short QT syndrome (SQT3) is caused by a mutation in the KCNJ2 gene. Circ Res. 2005; 96:800-7. [PubMed: 15761194]

10. Xia M, Jin Q, Bendahhou S, He Y, Larroque MM, Chen Y, Zhou Q, Yang Y, Liu Y, Liu B, Zhu Q, Zhou Y, Lin J, Liang B, Li L, Dong X, Pan Z, Wang R, Wan H, Qiu W, Xu W, Eurlings P, Barhanin J. A Kir2.1 gain-of-function mutation underlies familial atrial fibrillation. Biochem Biophys Res Commun. 2005; 332:1012-9. [PubMed: 15922306]

11. Li J, McLerie M, Lopatin AN. Transgenic upregulation of $\mathrm{I}_{\mathrm{K} 1}$ in the mouse heart leads to multiple abnormalities of cardiac excitability. Am J Physiol Heart Circ Physiol. 2004; 287:H2790-802. [PubMed: 15271672]

12. Noujaim SF, Pandit SV, Berenfeld O, Vikstrom K, Cerrone M, Mironov S, Zugermayr M, Lopatin AN, Jalife J. Up-regulation of the inward rectifier $\mathrm{K}^{+}$current $\left(\mathrm{I}_{\mathrm{K} 1}\right)$ in the mouse heart accelerates and stabilizes rotors. J Physiol. 2007; 578:315-26. [PubMed: 17095564] 
13. Keating MT, Sanguinetti MC. Molecular and cellular mechanisms of cardiac arrhythmias. Cell. 2001; 104:569-80. [PubMed: 11239413]

14. Kannankeril PJ, Roden DM. Drug-induced long QT and torsade de pointes: recent advances. Curr Opin Cardiol. 2007; 22:39-43. [PubMed: 17143043]

15. Piao L, Li J, McLerie M, Lopatin AN. Cardiac $\mathrm{I}_{\mathrm{K} 1}$ underlies early action potential shortening during hypoxia in the mouse heart. Journal of Molecular and Cellular Cardiology. 2007

16. Lopes CM, Zhang H, Rohacs T, Jin T, Yang J, Logothetis DE. Alterations in conserved Kir channel-PIP2 interactions underlie channelopathies. Neuron. 2002; 34:933-44. [PubMed: 12086641]

17. Ballester LY, Benson DW, Wong B, Law IH, Mathews KD, Vanoye CG, George AL Jr. Trafficking-competent and trafficking-defective KCNJ2 mutations in Andersen syndrome. Hum Mutat. 2006; 27:388. [PubMed: 16541386]

18. Nagase S, Kusano KF, Yoshida M, Ohe T. Electrophysiologic characteristics of an Andersen syndrome patient with KCNJ2 mutation. Heart Rhythm. 2007; 4:512-5. [PubMed: 17399643]

19. Sung RJ, Wu SN, Wu JS, Chang HD, Luo CH. Electrophysiological mechanisms of ventricular arrhythmias in relation to Andersen-Tawil syndrome under conditions of reduced $\mathrm{I}_{\mathrm{K} 1}$ : a simulation study. Am J Physiol Heart Circ Physiol. 2006; 291:H2597-605. [PubMed: 16877549]

20. Seemann G, Sachse FB, Weiss DL, Ptacek LJ, Tristani-Firouzi M. Modeling of $\mathrm{I}_{\mathrm{K} 1}$ mutations in human left ventricular myocytes and tissue. Am J Physiol Heart Circ Physiol. 2007; 292:H549-59. [PubMed: 16936001]

21. Tsuboi M, Antzelevitch C. Cellular basis for electrocardiographic and arrhythmic manifestations of Andersen-Tawil syndrome (LQT7). Heart Rhythm. 2006; 3:328-35. [PubMed: 16500306]

22. Nattel S. Remodeling of cardiac inward-rectifier currents: an often-overlooked contributor to arrhythmogenic states. J Mol Cell Cardiol. 2003; 35:1395-8. [PubMed: 14654365]

23. Fauconnier J, Lacampagne A, Rauzier JM, Vassort G, Richard S. Ca ${ }^{2+}$-dependent reduction of $\mathrm{I}_{\mathrm{K} 1}$ in rat ventricular cells: a novel paradigm for arrhythmia in heart failure? Cardiovasc Res. 2005; 68:204-12. [PubMed: 16083867]

24. Brugada R, Hong K, Dumaine R, Cordeiro J, Gaita F, Borggrefe M, Menendez TM, Brugada J, Pollevick GD, Wolpert C, Burashnikov E, Matsuo K, Wu YS, Guerchicoff A, Bianchi F, Giustetto C, Schimpf R, Brugada P, Antzelevitch C. Sudden death associated with short-QT syndrome linked to mutations in HERG. Circulation. 2004; 109:30-5. [PubMed: 14676148]

25. Bellocq C, van Ginneken AC, Bezzina CR, Alders M, Escande D, Mannens MM, Baro I, Wilde AA. Mutation in the $K C N Q 1$ gene leading to the short QT-interval syndrome. Circulation. 2004; 109:2394-7. [PubMed: 15159330]

26. Zhang H, Garratt CJ, Zhu J, Holden AV. Role of up-regulation of $\mathrm{I}_{\mathrm{K} 1}$ in action potential shortening associated with atrial fibrillation in humans. Cardiovasc Res. 2005; 66:493-502. [PubMed: 15914114]

27. Bryan J, Vila-Carriles WH, Zhao G, Babenko AP, Aguilar-Bryan L. Toward linking structure with function in ATP-sensitive $\mathrm{K}^{+}$channels. Diabetes. 2004; 53 (Suppl 3):S104-12. [PubMed: 15561897]

28. Miki T, Seino S. Roles of KATP channels as metabolic sensors in acute metabolic changes. J Mol Cell Cardiol. 2005; 38:917-25. [PubMed: 15910876]

29. Kane GC, Liu XK, Yamada S, Olson TM, Terzic A. Cardiac $\mathrm{K}_{\mathrm{ATP}}$ channels in health and disease. J Mol Cell Cardiol. 2005; 38:937-43. [PubMed: 15910878]

30. Ruiz-Petrich E, de Lorenzi F, Chartier D. Role of the inward rectifier $\mathrm{I}_{\mathrm{K} 1}$ in the myocardial response to hypoxia. Cardiovasc Res. 1991; 25:17-26. [PubMed: 2054826]

31. Muramatsu H, Sato R, Okumura $\mathrm{H}$. Early increase in $\mathrm{K}^{+}$conductance during metabolic inhibition by cyanide in guinea pig ventricular myocytes. Nippon Ika Daigaku Zasshi. 1990; 57:308-21. [PubMed: 2229329]

32. Lopatin AN, Makhina EN, Nichols CG. Potassium channel block by cytoplasmic polyamines as the mechanism of intrinsic rectification. Nature. 1994; 372:366-9. [PubMed: 7969496]

33. Ruiz Petrich E, Ponce Zumino A, Schanne OF. Early action potential shortening in hypoxic hearts: role of chloride current(s) mediated by catecholamine release. J Mol Cell Cardiol. 1996; 28:279_ 90. [PubMed: 8729060] 